Bartın Üniversitesi İktisadi ve İdari Bilimler Fakültesi Dergisi, 2021, Cilt 12, Sayı 23

Bartın University Journal of Faculty of Economics and Administrative Sciences, 2021, Volume 12, Issue 23

E-ISSN: 2148-2497

http://iibfdergi.bartin.edu.tr/

https://dergipark.org.tr/tr/pub/bartiniibf

Araştırma Makalesi, Gönderim Tarihi: 19.12.2021; Kabul Tarihi: 22.05.2021

\title{
12 Temmuz Beyannamesi Süreci ve Beyannamenin Türk Siyasal Hayatına Etkisi Üzerine Bir Değerlendirme
}

\author{
Doç. Dr. Hüseyin ÇAVUŞOĞLU \\ Zonguldak Bülent Ecevit Üniversitesi, Siyaset Bilimi ve Kamu Yönetimi Bölümü, \\ huseyindp@ hotmail.com, Orcid ID: 0000-0001-7132-3833.
}

\section{$\ddot{O} z$}

Bu çalışmada, 12 Temmuz beyannamesi süreci ve beyannamenin Türk siyasal yaşamına etkisi ele alınmıştır. Türkiye'de çok partili hayata geçildikten sonra, iktidar ile muhalefet arasındaki ilişki oldukça gerginleşti ve bu ortamda, Cumhurbaşkanı İsmet İnönü, iktidar ve muhalefet liderleriyle yaptığı görüşmeler sonucunda, "12 Temmuz Beyannamesini” yayımlamıştır. Beyanname ile DP, kurumsal bir kimlik kazanırken, iktidar ile muhalefet arasında karşılıklı bir güven ortamı yakalanmıştır. Beyannamenin hem CHP hem DP açısından önemli sonuçları olmuştur. CHP'de Başbakan Recep Peker istifa ederken; DP'de ise yaşanan ihraçlar ve istifalar sonunda Millet Partisi kurulmuştur. Beyanname, çok partili demokratik düzenin tesisi için gerekli olan bir önlem olarak, Türk siyasal hayatındaki yerini almıştır. Ayrıca Türkiye'nin çok partili hayattan yana olduğu mesajı, batılı ülkelere verilmiştir.

Anahtar Kelimeler: İsmet İnönü, iktidar, muhalefet, Recep Peker.

JEL Sınıflandırması: Z0

\section{An Evaluation on the Process of the 12th July Declaration and its Effect on Turkish Political Life}

\begin{abstract}
In this study, the process of the July 12 declaration and its effect on Turkish political life are discussed. After the transition to multi-party life in Turkey, relations between the government and the opposition were quite tense, and in this environment, President Ismet Inonu, as a result of his talks with government and opposition leaders, "July 12, Declaration on" was published. With the declaration, while the Democrat Party gained an institutional identity, an atmosphere of mutual trust was achieved between the government and the opposition. The declaration had important consequences for both CHP and DP. While Prime Minister Recep Peker resign from CHP; In DP, as a result of the dismissals and resignations, the Nation Party was established. The declaration has taken its place in Turkish political life as a necessary measure for the establishment of multi-party democratic order. In addition, the message that Turkey favors multi-party life was given to western countries.
\end{abstract}

Keywords: İsmet İnönü, government, opposition, Recep Peker.

JEL Classification: Z0 

and its Effect on Turkish Political Life

\section{Giriş}

Siyasal partiler, günümüzde demokrasinin en önemli unsurlardan biri olarak kabul edilmektedirler. Muhalefet de demokrasinin önemli temel değerlerindendir. Türk siyasal hayatı incelendiğinde, 23 Nisan 1920'de Türkiye Büyük Millet Meclisi'nin açılışı sonrası, parlamentoda birinci grup ve ikinci grup olarak adlandırılan 2 grubun ortaya çıktığı görülmektedir. Birinci grup, Mustafa Kemal Atatürk liderliğinde Cumhuriyet Halk Fırkasını (CHF) oluştururken; ikinci grup ise Kazım Karabekir önderliğinde Terakkiperver Cumhuriyet Halk Fırkasını (TPCF) kurmuştur. Kendini muhafazakâr, demokrat bir parti olarak tanımlayan TPCF, Türkiye Cumhuriyeti'nin ilk muhalefet partisi olup, Rauf Orbay, Refet Bele ve Ali Fuat Cebesoy gibi önemli isimler partide yer almıştır. 13 Şubat 1925'te Diyarbakır'ın Ergani ilçesinde başlayan ve bölgeye yayılan Şeyh Sait isyanı sonrası, Takriri Sükûn (Huzurun Sağlanması) kanunu çıkarılmış, yapılan yargılamada, TPCF'nin bazı yöneticileri bu isyana destek vermekle suçlanmıştır. 17 Kasım 1924 'te kurulan Türkiye'nin ilk muhalefet partisinin siyasal ömrü, oldukça kısa sürmüş ve TPCF, 5 Haziran 1925'te kapatılmıştır. 1930 yılına gelindiğinde, güdümlü bir muhalefet partisi deneyimine gidilmiştir. Atatürk'ün isteği, desteğiyle dönemin Paris Büyükelçisi Fethi Okyar'ın genel başkanlığında 12 Ağustos 1930'da Serbest Cumhuriyet Fırkası (SCF) kurulmuştur. Atatürk'ün yakın arkadaşları ve kız kardeşi Makbule Hanım partide yer alırken, CHF'den 15 milletvekili istifa ederek SCF'ye katıldılar. SCF'nin İzmir'de düzenlediği mitingin, parti tarihinde önemli bir yere vardır. Büyük bir katılımla gerçekleştirilen mitingte, bir grubun Atatürk ve CHF aleyhine sloganlar atmasıyla çıkan olaylarda bir çocuk, polis kurşunu ile hayatını kaybetmiştir. 1929 Ekonomik Buhranı, tüm ülkeler gibi Türkiye'yi de etkilemişti. Türkiye'nin özellikle ekonomik durumundan sıkıntı çeken sınıfların, SCF'de toplandığı ve İzmir mitingi ile SCF'nın ilerleyen süreçte güçlü bir iktidar adayı olabileceği belirtilmektedir. Bu ortamda, Atatürk SCF'den desteğini çekmiş ve 17 Kasım1930'da SCF kendini feshetmiştir. Böylece, tek parti döneminde çok partili bir düzene geçilememiştir (Altınkaş, 2012: 2-14).

II. Dünya Savaşı'nda Türkiye, tarafsızlığını korumuş ve savaş 1945 'te sona ermiştir. II. Dünya Savaşı'nı kazanan devletler, demokratik devletler olarak isimlendirilmiş ve savaş sonrası demokratik yönetimler ön plana çıkmıştır. Bu dönemde, Sovyetler Birliği'nin 1925 tarihli Saldırmazlık Antlaşmasını yenilemeyeceğini duyurması, toprak talebi, boğazlarda ortak yönetim gibi Türkiye'ye yönelik ciddi tehditleri olmuştur. Türkiye, II. Dünya Savaşı sonrası, demokrasinin batı ile özdeşleştiği bir ortamda, Sovyetler Birliği'nin tehditlerine karşı batılı devletlerin desteğini alabilmek için, batı gibi demokratik bir ülke olarak görünmek istemiştir. Nisan 1945 'ten Haziran 1945'e kadar San Francisco'da BM öncülüğünde 50'den fazla ülkenin katıldı̆̆ toplantılara, Türk heyeti de katılmış ve çok partili hayata en kısa sürede geçileceğine vurgu yapılmıştı. Diğer taraftan Cumhurbaşkanı İnönü, 19 Mayıs 1945 ve Meclis açılışında yaptığı konuşmalarda, en kısa sürede çok partili hayata geçileceğini söylemiştir (Kara, 1984: 64-69). 
7 Haziran 1945'te Celal Bayar, Adnan Menderes, Fuat Köprülü ve Refik Koraltan imzalı önerge, CHP Meclis Grubuna verilmiştir. Dörtlü Takrir olarak bilinen belgede, ana hatlarıyla anayasa, kanunlar ve CHP Parti tüzüğündeki demokratik olmayan maddelerin çıkarılması, TBMM'nin iktidarı denetlemesine gerçek manada izin verilmesi ve seçimlerin yarg1 denetiminde yapılması istenmiştir. 12 Haziran'da CHP Meclis Grubu'nda önerge, reddedilmiştir. Dörtlü Takrir'in reddedilmesinden sonra CHP'yi eleştiren yazılar kaleme alan Adnan Menderes, Fuat Köprülü ve Refik Koraltan partiden ihraç edilmişlerdir. İhraçlar sonrası, parti kurma çalışmalarına hız verilmiştir. 4 Aralık 1945 günü Celal Bayar, Cumhurbaşkanı İsmet İnönü ile görüşmüş ve kurulacak parti için İnönü'nün onayını almıştır. 7 Ocak 1946'da Türk siyasal hayatının en önemli partilerinden biri olan Demokrat Parti (DP) kurulmuştur. DP'nin 1947 yılındaki genel seçimlere iyi bir biçimde hazırlanmasını engelleyebilmek adına, CHP 21 Temmuz 1946'da genel seçimlerin yapılmasına karar vermiştir. 21 Temmuz 1946 genel seçimlerinde DP, 16 ilde aday gösterememiştir. Açık oy gizli sayım ilkesi ile yapılan 1946 seçimlerinde, usulsüzlükler ve baskılar yaşanmıştır. Bundan dolayı, 1946 seçimleri, İttihat ve Terakki döneminde yapılan 1912 seçimlerine (Sopalı seçimlere) benzetilmektedir. DP, 465 milletvekilliği için 273 aday gösterebilmiş ve 21 Temmuz 1946 seçimlerinde CHP, tek başına iktidara gelirken; DP 62 milletvekili ile Meclis'e girmiştir (Eroğul, 1998: 11-23; Yücel, 2001: 46-56).

$\mathrm{Bu}$ noktada sırasıyla çalışmanın konusu, amacı, önemi ve yöntemine değinilecektir. 21 Temmuz 1946 genel seçimleri sonrası, sert açıklamalarla iktidarmuhalefet arasındaki ilişki gerginleşmiştir. Bu noktada Cumhurbaşkanı İsmet İnönü, 12 Temmuz Beyannamesini yayımlanmıştır. Bu çalışmada, 12 Temmuz beyannamesi süreci ve beyannamenin Türk siyasal yaşamına etkisi ele alınmış olup, çalışmanın amacı, 12 Temmuz beyannamesi sürecinde yaşananları ve beyannamenin Türk siyasal yaşamı üzerindeki etkisini ortaya koymaktır. Bu bağlamda, 1946 genel seçimleri sonrası kurulan Recep Peker hükümetinin kuruluş süreci, hükümet ile muhalefet arasındaki çatışma noktaları, 12 Temmuz beyannamesi ayrıntılı bir biçimde ele alınmış ve daha sonra beyannamenin DP ve CHP açısından sonuçlarına değinilmiştir. Çalışmanın önemi değerlendirildiğinde, batıya, San Francisco'da BM öncülüğünde yapılan toplantılarda, Türkiye'nin çok partili hayata en kısa zamanda geçeceği yönünde sözler verilmişti. 12 Temmuz beyannamesi ile de Türkiye'nin çok partili yaşama geçtiği, bu düzene devam edeceği ve demokratik hayattan geri dönüşün söz konusu olmayacağı mesajı verilmiştir. Ayrıca, çalışmanın önemi ile ilgili olarak, 12 Temmuz Beyannamesinin, muhalefetin kimlik kazanmasında, önemli bir işlev gördüğü söylenebilir. Çalışmada, "Var olan kayıt ve belgeleri inceleyerek veri toplama" olarak tanımlanan "Belgesel Tarama" tekniği kullanılmıştır. Belgesel tarama tekniği kaynaklara ulaşma, okuma, fişleme (not alma) ve değerlendirme olmak üzere dört aşamada gerçekleştirilmiştir. Genel tarama (literatür taraması) amaçlı, belgesel tarama tekniğine yer verilmiştir (Karasar, 1991:183-184).

\section{Recep Peker Hükümetinin Kurulması}

21 Temmuz 1946 genel seçimlerinden sonra Başbakanın kim olacağı konusunda bir belirsizlik yaşandığı söylenebilir. Başbakanlık teklifi önce Hilmi Uran'a yapılmıştı. 
Uran'ın kabul etmemesi üzerine teklif, Recep Peker'e yapılmış ve Peker, başbakanlığ kabul etmiştir. Peker, CHP içinde önemli siyasetçilerden, CHP'nin ilk genel sekreteri olup, Milli Savunma ve İçişleri Bakanlığı gibi önemli görevlerde yer almıştır. Peker'e, "Parti Genel Başkan Vekilliğii” görevi verilmemiştir. Çok partili düzene yeni geçilmiş iken; başbakanlık ile parti genel başkan vekilliğinin farklı kişilere verilmesi düşünülmüştür. Parti genel başkan vekilliğine, Şükrü Saraçoğlu getirilmiştir. Bu dönem, Türkiye'nin siyasal hayatı, demokratik düzeni için oldukça hassas bir süreçti. Çok kısa bir süre önce çok partili hayata geçildiğinden dolayı, çoğu siyasetçi başbakanlık gibi ağır bir sorumluluğu almak istememiştir (Tuna, 2006: 42-45). Recep Peker Hükümeti'nde bakanlıkların dağılımı şöyledir: “Başbakan: Recep Peker (Ístanbul), Adalet Bakanı: Mümtaz Ökmen (Ankara), Milli Savunma bakanı: Cemil Cahit Toydemir (İstanbul), İ̧işleri Bakanı: Şükrü Sökmensüer (Gümüşhane), Dışişleri Bakanı: Hasan Saka (Trabzon), Maliye Bakanı: Halit Nazmi Keşmir (Tokat), Milli Eğitim Bakanı: Reşat Şemsettin Sirer (Sivas), Bayındırlık Bakanı: Cevdet Kerim Incedayı (Sinop), Ekonomi Bakanı: Tahsin Bekir Balta (Rize), Sağlık ve Sosyal Yardım Bakanı: Behçet Uz (Denizli), Gümrük ve Tekel Bakanı: Tahsin Çoşkun (Kastamonu), Tarım Bakanı: Faik Kurdoğlu (Manisa), Ulaştırma Bakanı: Şükrü Koçak (Erzurum), Ticaret Bakanı: Atıf İnan (İzmir), Çalışma Bakanı: Sadi ırmak (Konya)“ (TBMM, 1946: 12).

5 Ağustos 1946'da Recep Peker hükümeti TBMM'den güvenoyu aldı. Muhalefet ile ilk tartışma, 14 Ağustos'ta hükümet programının mecliste görüşülmesi esnasında yaşand1. Hükümet programı okunduktan sonra DP'den Fuat Köprülü, programı her yönüyle değerlendirebilmek için iki gün süre istemiş fakat bu istek, CHP'liler tarafından kabul edilmemiştir. Karşılıklı sert sözlerden sonra hükümet programı 53 hayır oyuna karşı 378 evet oyu ile kabul edilmiştir (Dereli, 1996: 13-15).

\section{Hükümet İle Muhalefet Arasındaki Çatışma Konuları}

Recep Peker hükümetinin ilk icraatı, halkın önemli sorunlarından biri olan ekonomi le ilgiliydi. Ekonomik istikrarın sağlanması için Türk Lirasının değerini düşürmeyi içeren "7 Eylül Kararları", Peker hükümetinin attığı ilk adım olmuştur. Fakat bu kararlar, ekonomide bekleneni verememiş, aksine fiyatların daha da artmasına, hayat pahalılığına neden olmuştur. DP, 7 Eylül kararlarından dolayı CHP'yi sert bir biçimde eleştirmiş. Başbakan, aynı sertlikte cevap vermiştir. İnönü de iktidar muhalefet arasındaki bu tartışmayı "muhalefetinde bir gün iktidar olabileceğini" söyleyerek, iki parti arasındaki gerilimi azaltmaya, dağıtmaya çalışmıştır (Ahmad, 2007: 39; Karpat, 2008: 279-282).

Hükümet, Aralık 1946'da hem yurtiçi hem de uluslararası ortamı gerekçe göstererek İstanbul, Edirne, Kırklareli, Tekirdağ, Çanakkale ve Kocaeli'nde sıkıyönetimi altı ay uzatma kararı almıştır. DP'liler ise hükümetin gazeteleri kapatmak, mitinglerin yapılmasını önlemek için bu yola başvurduğunu öne sürmüştür. 4 Aralık'ta altı ilde sıkıyönetim altı ay daha uzatılmıştır. Bu karardan sonra 6 Ocak 1947'de sınıfsal çatışmayı savunarak suç işlediği öne sürülen altı gazete ve dergi süresiz kapatılıştır (Karpat, 1996: 155). 
CHP ile DP arasındaki en önemli tartışma, 18 Aralık 1946'da başlayan 1947 bütçe görüşmelerinde yaşanmıştır. Başbakan Recep Peker'in konuşmasından sonra söz alan DP milletvekili Adnan Menderes, bütçedeki önlemlerin yeterli olmadığını, kırsal kesime yeteri kadar destek verilmediğini, tasarruf önlemlerinin gerçekçi olmadığını, bürokrasi ve vergi sisteminde kökten değişiklik yapılması gerektiğini söylemiştir. Menderes'ten sonra Başbakan'ın yaptığı konuşma, CHP ile DP arasındaki iplerin kopmasına neden olmuştur. Peker'in konuşmasından bir bölüm şöyledir: "Muhterem arkadaşlarım, Demokrat Parti adına dinlediğiniz Adnan Menderes'in sesinde kötümser ve psikopat bir ruhun mariz karanlıklar içinde şanlı bir milletin ve arkada bıraktığ karanlıklardan azametli, şan ve şerefli bir istikbale gitmek azminde bulunan kudretli bir devletin hayatını bir boşluk halinde ifade eden ruh hâletinin akislerini dinledik..." Görüldüğü üzere Başbakan Peker "Psikopat bir ruhun ifadesi" şeklinde Menderes'in konuşmasını değerlendirmiştir. Başbakanın bu sert konuşması üzerine DP'liler TBMM'yi terk etmişlerdir. Bu durum karşısında Cumhurbaşkanı İnönü, iki parti arasında arabuluculuğa soyunmuş ve 22 Aralık'ta Çankaya Köşkü'nde Recep Peker ve Celal Bayar ile görüşmüş, 24 Aralık’ta Celal Bayar'ı Çankaya Köşkü'ne tekrar davet etmiştir. İnönü, yaptığ 1 görüşmelerde taraflardan siyasal sistemin işlemesini istemiştir. DP, Cumhurbaşkanının talebini, yaklaşmakta olan büyük kongreyi de dikkate alarak 9 gün sonra 27 Aralık'ta bütçe görüşmelerine katılmıştır. 48 hayır oyuna karşı 354 evet oyu ile 1947 yılı bütçesi kabul edilmiştir (Sat1, 2019: 148-150; Nalbant, 2014: 41-42). Bütçe görüşmesi sonrası yaşananlar, DP'nin Meclis'i terk etmesi, çok partili hayatın hassaslığını ortaya koymuştur.

DP Birinci Büyük Kongresi, 7 Ocak 1947'de yapıldı ve 11 Ocak'ta sona erdi. 548 delegeden 541'inin oyunu alarak, DP Genel Başkanlığına yeniden Celal Bayar seçildi. Ana Davalar Komisyonu Raporu "Hürriyet Misakı" olarak adlandırıldı. Rapora bu ismin verilmesinde "Misakı Milliye" bir atıf olduğu söylenebilir (Zürcher, 2006: 310). Hürriyet Misakına göre; anayasaya aykırı yasaların çıkarılması, cumhurbaşkanlığı ile parti genel başkanlığı vekilliğinin tek kişide toplanmaması, yürürlükte olan seçim yasasının değiştirilmesi, hükümetten istenmiştir. Ayrıca bu belgede, bu isteklerin hükümet tarafından yerine getirilmemesi durumunda, DP'nin TBMM'den çekileceği de belirtilmiştir (Eroğul, 1998: 46-51). DP'nin meclisten çekilmesi, CHP'yi tek parti durumuna düşürecekti ve çok partili hayat geçişe önemli bir darbe vurulmuş olacaktı. Kongrede muhalif grup, bütün milletvekillerinin istifa etmesini istemiş, fakat bu istek kabul edilmemiştir (Çiçek, 2018: 87). Bu kongre ile DP, iktidar için önemli bir alternatif olduğunu Türk halkına göstermiştir. DP Birinci Büyük Kongresi, demokratik bir ortamda gerçekleşmiş, delegeler düşüncelerini özgürce ifade etmişlerdir. Kongrenin, iktidar-muhalefet arasındaki gerginliği hem arttırdığ hem de Cumhurbaşkanının iktidar ve muhalefet partilerine tarafsız, eşit bir biçimde davranmasının yolunu açtığ söylenebilir (Öztürkci, 2019: 753).

DP, 6 Nisan 1947'de yapılacak ara seçimler için İzmir'de toplanma kararı almıştı. Başbakan Recep Peker, DP'den önce İzmir'e gelmiş ve Halkevin'de yaptığ 1 konuşmada İstiklal Mahkemeleri ile ilgili kanunun yürürlükte olduğuna vurgu yapmıştır. Başbakanın bu açıklaması üzerine DP İstanbul, Balıkesir, Kastamonu ve 
Tekirdağ'da yapılacak ara seçimlere girmeme kararı almış ve CHP ile DP arasındaki ipler kopma noktasına gelmişti. Menderes, Başbakanın bu sözlerine çok sert bir açıklama yapmıştır. Menderes'in “Memlekette demokrasi devrini açıyoruz, iddiasını ileri sürenler bu devri hile fesat ve zor kullanma temeli üzerine kuracaklarını farz ediyorlar" şeklinde sözlerinden sonra CHP, Menderes'in dokunulmazlığının kaldırılmasını talep etmiş ve bu karar dönem sonuna bırakılmıştır. Komisyon, 11 Şubat 1948 tarihinde Menderes'in dokunulmazlığının kaldırılmasına gerek görmemiştir (Ahmad, 2007: 99).

16 Şubat 1947 'de muhtarlık seçimi yapıldı. 33.328 köyden 30.133'ünün CHP, 1235'inde DP, 1960'ını ise bağımsılar kazanmıştır. Seçimlerde çıkan olaylarda altı kişi hayatını kaybetmiştir. Adnan Menderes, Uşak ve Kütahya'da yaptığı konuşmalarda, muhtarlık seçimlerinde iktidar baskısından söz edip hükümeti suçlamış, seçimlerde usulsüzlük yapıldığını ve bu durumun demokratik düzenin gelişmesine engel olduğunu vurgulamıştır. 1947 muhtarlık seçimleri, Mersin Arslanköy'deki usulsüzlük ile anılmaktadır (Dereli, 1996: 56; Uçan, 2014: 139).

\section{12 Temmuz Beyannamesi}

12 Temmuz'a giden süreçte İngiltere'ye yapılan ziyaretin önemli bir yeri vardır. 10 Mayıs 1947 'de İngiliz Parlamentosunun daveti üzerine aralarında DP'den Fuad Köprülü ve Enis Akaygen ve CHP'den heyete başkanlık eden Hüseyin Cahit Yalçın, Nihat Erim gibi isimlerin yer aldığı milletvekilleri Londra'ya gittiler. Heyetin ziyareti 6 Haziran'a kadar sürmüştür. Erim ve Köprülü arasında yapılan görüşmelerde, DP ile CHP arasındaki ilişkinin bir düzene oturtulması, uzlaşmanın gereği, anlaşmazlık noktalarının çözümlenmesi ve iki parti arasında bir dostluğun başlaması konusunda anlaşmaya varılmıştır. Nihat Erim'in İsmet İnönü ile yakınlığı herkes tarafindan bilinmekteydi. Bazı bilim insanları tarafından 12 Temmuz beyannamesi sürecinin bu gezi ile başladığı ifade edilmektedir (Arcayürek, 1983: 130).

İktidar ile muhalefet arasındaki ilişkinin gerginleştiği bu ortamda, Cumhurbaşkanı İsmet İnönü, iktidar ile muhalefet arasında arabuluculuk görevine soyunmuştur. Cumhurbaşkanı, konumu gereği Başbakan Recep Peker ve DP lideri Celal Bayar ile yaptığı görüşmeleri, tarafsız bir biçimde değerlendirmiştir. Cumhurbaşkanı İsmet İnönü ile DP lideri Celal Bayar arasındaki ilk görüşme, 7 Haziran'da gerçekleşti. İnönü ile Bayar, 11, 14, 17.20, 26 Haziran ve 5, 7, 10 Temmuz'da görüşmelerine devam ettiler. Üzeyir Avunduk, Vehbi Koç, Mümtaz Ökmen, Hamdullah Suphi Tanrı̈ver gibi isimler, İnönü ile Bayar arasında arabuluculuk yaptılar. 14 Haziran'da İnönü liderliğinde Recep Peker ve Celal Bayar bir araya gelmişlerdir. Bu görüşme, her iki parti liderinin karşılıklı suçlamaları ile geçmiştir. Baştan beri, DP ile temasa karşı olan Recep Peker, görüşmelerin devamından yana olmadığını belirtmesine rağmen görüşmeler devam etmiştir. 26 Haziran'daki görüşmede, İnönü, Bayar'a görüşmelerin neticesinde bir bildirinin yayımlanmasını önerdi. Bayar, bu öneriyi kabul ederken; Recep Peker ise bu bildirinin CHP'yi zayıf bir konuma düşüreceğini ileri sürerek kabul etmemiştir. Bildirinin taslağı, 2 Temmuz'da ortaya çıkmıştır. Parti başkanlığı ile 
Cumhurbaşkanlığının aynı kişide toplanmayacağına ilişkin görüşler, Başbakan Recep Peker'in itirazı ile bildiriden çıkarıldı ve Peker'in itirazlarıyla bildiri on sayfadan altı sayfaya kadar indi. Peker, beyannameye tepkisini 2 Temmuz'da izne çıkarak, İstanbul'a giderek gösterdi. Beyanname 11 Temmuz günü önce radyoda okundu ve 12 Temmuz'da gazetelerde yayımlandı (Gökçeler, 2018: 73-83; Akın, 2005: 93-98). Beyannamede İnönü, Celal Bayar ve Recep Peker ile yaptığı temasları ve bu temaslarla ilgili fikirlerini dile getirmiştir. Bildiriye bakıldığında, bir iktidar baskısına değinilirken; muhalefetin yani DP'nin ihtilalci olmadığına ve Cumhurbaşkanının her iki partiye eşit mesafede olduğuna vurgu yapılmıştır. 12 Temmuz beyannamesi İsmet İnönü’ye göre, çok partili demokratik düzenin tesisi için gerekli olan bir önlem olarak Türk siyasal hayatında yerini almıştır (Avcıoğlu, 1959: 11).

\section{Beyanname Sonrası Gelişmeler}

Başbakan Recep Peker, 26 Ağustos 1947'de yapılan CHP Grup toplantısında güvenoyu istemiştir. Peker, 35'e karş1 303 oyla parti grubundan güvenoyunu almıştır. CHP tarihinde, bu güne kadar ki güven oylamaları, oy birliği ile alınmıştı. 26 Ağustos 1947'deki güven oylamasında, 35 ret oyunun çıkması, Peker hükümeti için güvensizlik anlamına gelmekteydi. Güven oylaması sonrası Türk siyasal hayatında "35'ler Olayı"” olarak tarihe geçen ve liderinin Nihat Erim olduğu hareket ortaya çıkmıştır (Ahmad, 1992, 40-41; Tunaya, 1952: 563-564).

Başbakan Recep Peker, 26 Ağustos'taki güven oylamasından sonra hükümette değişikliğe gitmek istemiştir. İnönü'de bu değişikliğe CHP Meclis Grubundan onay alması şartıyla olabileceğini dile getirmiştir. CHP Meclis Grubunda 4 Eylül'de yapılan oylamada 47 ret oyuna karşı 194 kabul oyu ile hükümetteki değişikliğe onay verilmiştir.

Tablo 1: Kabine Değişikliği

\begin{tabular}{|l|l|}
\hline Görevden Alınanlar & Yeni Atananlar \\
\hline İçişleri Bakanı Şükrü Sökmensüer & M. Hüsrev Göle \\
\hline Ticaret Bakanı Atıf İnan & H. Nazmi Keşmir (Vekaleten) \\
\hline Milli Müdafaa Bakanı C. Cahit Toydemir & Münif Birsel \\
\hline Tarım Bakanı Faik Kurdoğlu & Şevket Adalı \\
\hline
\end{tabular}

\footnotetext{
${ }^{1}$ Grup toplantısında ret oyu veren kişiler şu isimlerden oluşmaktaydı: "Nihat Erim, Vedat Dicleli, Kasım Gülek, Kasım Eren, İ. Rüştü Aksal, Cavit Oral, Sinan Tekelioğlu, Fahir Kurtuluş, Mahmut N. Gündüzalp, Cevat Dursunoğlu, H. Suphi Tanrı̈ver, C. Sait Siren, Şevket R: Hatipoğlu, A. Fuat Cebesoy, Nazif Erkin, Tahsin Banguoğlu, Tezer Taşkıran, İ. Hamit Tigrel, Sait Odyak, Sedat Çumralı, Muhsin Adil Binal, Hasan Ş. Adsal, Avni Refik Bekman, Muhtar Ertan, Ali Kemal Yiğitoğlu, Abdurrahman Melek, Vehbi Sarıdal, Hilmi Atlıŏlu, Kamil Kitapçı, Hilmi Öztarhan, Suut Kemal Yetkin, Raşit Börekçi, Osman Agan, Bekir Kaleli, M. Şevket Esendal.”
} 


\begin{tabular}{|l|l|}
\hline Çalışma Bakanı Sadi Irmak & T. Bekir Balta \\
\hline Ekonomi Bakanı T. Bekir Balta & Cevat Etkin \\
\hline
\end{tabular}

Kaynak: Tuna, S. (2006).

Bu oylamadan dört gün sonra yapılan CHP Parti Divanında Recep Peker, parti genel başkanlığı vekilliği ile başbakanlığın bir arada olması gerektiğini belirtmiştir. Fakat CHP Parti Divanından bu desteği alamamıştır. Bunun üzerine Başbakan Recep Peker, bir gün sonra sağlık durumunu gerekçe göstererek istifa etmiştir (Albayrak, 2004: 122).

Cumhurbaşkanı İnönü, Recep Peker'in istifasından kısa bir süre sonra, Doğu Anadolu ve Karadeniz'i kapsayan geziye çıktı. 14 Eylül'de başlayan bu geziye katılanlar arasında, İnönü'nün eşi Mevhibe hanım, aralarında Nihat Erim'in yer aldığı bazı CHP milletvekilleri ve DP milletvekili Nuri Özsan'ın yer aldığı bir heyet yer almaktaydı. İnönü, geziye çıkmadan önce Bayar ile yaptığı görüşmede, geziye DP'den de bir milletvekilinin katılmasını istemiştir. Böylece, geziye katılmak üzere Nuri Özsan seçilmiştir. Bu geziye DP'nin katılması, muhalefetin meşruiyetinin kabul edildiği anlamına gelmektedir. Cumhurbaşkanını uğurlayanlar arasında DP'den Fuad Köprülü de vardı (Akın, 2009: 57; Ateş ve Gökçeler, 2019: 485).

Cumhurbaşkanı İsmet İnönü'nün yurtiçi gezilerinin amacı, 12 Temmuz Beyannamesinde olduğu gibi demokratik düzenin devam ettiğiydi. İnönü'nün yurtiçi gezisinin ilk durağı, Erzurum'du. İnönü, DP'nin kuruluşundan bu yana ilk defa DP'nin örgütüne ziyaret gerçekleştirdi. Erzurum'dan sonra Kars, Ardahan, Gümüşhane, Trabzon, Rize, Ordu, Giresun ve Samsun'a gerçekleştirdiği ziyaretlerde de DP teşkilatına uğramıştır. İnönü'nün gezilerinde, çok partili hayata geçişin devamı için iktidar ile muhalefet arasında uzlaşma olmasına, çok partilin hayatın önemine, iktidar mensuplarının tarafsız davranmasına, güven ortamının yaratılmasının önemine, tarafsızlık, adalet ve eşitlik ilkelerine vurgu yaptığı görülmektedir. Siyasette "sayg1, hoşgörü, anlayış ve uzlaşma" ortamının ortaya çıkmasında bu gezilerin etkili olduğu, halkın iktidar-muhalefet ile ilgili görüşlerini ve halkın taleplerini dinlemek için İnönü'nün bu geziye çıktığı söylenebilir. İnönü’nün yurtiçi gezisi 26 Eylül'de sona ermiştir. İnönü ve beraberindeki heyeti, CHP ve DP'li milletvekilleri karşılamıştır (Çelebi, 2017: 290-95).

12 Temmuz beyannamesinin DP açısından sonucuna baktığımızda, DP içindeki muhalif grup, 12 Temmuz Beyannamesi ile DP'li yöneticileri CHP ile bir anlaşma yapmakla suçladılar ve Hürriyet Misakını hatırlatarak, DP’nin derhal TBMM'den çekilmesini talep ettiler. Bunun üzerine muhalif grubun öne çıkan isimlerinden Sadık Aldoğan, Osman Nuri Köni, Necati Erdem, Mithat Sakaroğlu, Kemal Silivrili yaptıkları açıklamalarla partiyi zayıflattıkları gerekçesiyle DP'den ihraç edildiler. Bu ihraçlara tepki olarak GİK’ten 6 kişi görevlerinden istifa etti. DP yönetimi, istifa eden Yusuf 
Kemal Tengirşenk, Enis Akaygen, Emin Sazak, Ahmet Tahtakılıç, Hasan Dinçer ve Ahmet Oğuz'u partiden ihraç etmiştir. Daha sonra da DP'de yaşanan ihraç ve istifalarla DP'nin milletvekili sayısı 31'e kadar düştü. DP'den istifa ve ihraç edilen milletvekillerinin bir bölümü, TBMM'de "Müstakil Demokratlar" grubunu kurarken; bir bölümü de Hikmet Bayur'un genel başkanlığında Millet Partisi'ni kurdular. Daha sonraki süreçte Müstakil Demokratlar grubu, Millet Partisi'ne katıldı (Ugan, 2014: 119121).

\section{Sonuç}

12 Temmuz beyannamesi süreci ve beyannamenin Türk siyasal yaşamına etkisinin ele alındığı bu çalışmada, 21 Temmuz 1946 genel seçimleriyle Recep Peker'in Başbakanlığı sonrası karşılıklı sert söylemlerle iktidar ile DP arasındaki ilişkinin kopma noktasına geldiği görülmektedir. 7 Eylül kararları, matbuat kanunu, sıkıyönetimin uzatılması, bütçe görüşmesi, DP Birinci Büyük Kongre'nde Hürriyet Misakı'nın kabul edilmesi, muhtarlık seçimi, İstiklal Mahkemeleri ile ilgili kanunun hala geçerli olduğunun anımsatılması, dokunulmazlıkların kaldırılmasına ilişkin DP'den 4 milletvekili ile ilgili teklifin TBMM'ye sunulması gibi hususlar ve DP'nin bir iktidar baskısını dile getirmesi diğer taraftan iktidarın da muhalefeti ihtilalci olmakla suçlaması, iktidar ile muhalefet arasındaki ilişkiyi germiştir. Böyle bir ortamda Cumhurbaşkanı İsmet İnönü, arabuluculuk görevi üstlenip, çok partili hayatın devamı için iktidar ile muhalefet arasında temas kurmuş ve bu temaslar sonucunda, Türk siyasal hayatına "12 Temmuz Beyannamesi" olarak geçen bildiriyi kaleme almıştır. DP'nin Meclis’i terk etmesi durumunda, ülkedeki rejim otoriter, tek partiye dönüşebilirdi. Bu ortamda, Cumhurbaşkanının 12 Temmuz Beyannamesi ile attığı adımın önemi ortaya çıkmaktadır. Beyannamenin hem CHP hem DP açısından önemli sonuçları olmuştur. CHP'de Başbakan Recep Peker istifa ederken; DP'de ise bir bölünme yaşanmıştır. DP'de yaşanan ihraçlar ve istifalar sonunda Millet Partisi kurulmuştur.

12 Temmuz beyannamesinin Türk siyasal hayatındaki yeri ve önemini daha iyi anlayabilmek için, sonrasında yaşanan gelişmeleri incelemek gerekir. Cumhurbaşkanı İnönü, 12 Temmuz beyannamesinden kısa bir süre sonra Doğu Anadolu ve Karadeniz'i kapsayan geziye çıkmış ve bu geziye DP de temsilci göndermiştir. Bu geziye, DP'nin katılması, muhalefetin meşruiyetinin kabul edilmesi olarak değerlendirilebilir. İnönü'nün, DP örgütlerini ziyaret ederek, 12 Temmuz'un en önemli amaçlarından birini gerçekleştirdiği söylenebilir. İnönü'nün bu gezisi, 12 Temmuz Beyannamesi doğrultusunda, Cumhurbaşkanının iktidar ile muhalefet arasında tarafsız olacağına bir kanıt olarak gösterilebilir. 1949 yılında Başbakanlığa gelen Şemsettin Günaltay'ın DP'yi ziyareti ve hükümet programını DP'ye vermesi ile çok partili hayatın devamı için çok önemli olan iktidar-muhalefet arasındaki yakınlaşma sağlanmıştır. Yine Şemsettin Günaltay döneminde gizli oy açık sayım ilkesi ve yargı denetiminde seçimlerin yapılmasını öngören seçim kanununun yürürlüğe girmesi, 12 Temmuz Beyannamesinin bir sonucu olarak görülebilir. Bunun yanında 12 Temmuz beyannamesi ile Cumhurbaşkanı İsmet İnönü’nün, tarafsızlığını ortaya koyarak, halkın büyük bir bölümünün sevgisini kazandığı söylenebilir. 

and its Effect on Turkish Political Life

Beyannamenin, muhalefet açısından öneminin, DP'ye devletin en üst makamı tarafindan güvenceler verilmesi ve muhalefetin kurumsal bir kimlik kazanmasına önemli bir fayda sağlaması olduğu ifade edilebilir. Bu beyanname ile iktidar ile muhalefet arasında karşılıklı bir güvenin tesisi amaçlanmış, bu bildirinin, özellikle batılı devletlere Türkiye'nin çok partili hayata geçtiğini, bu düzene devam edeceğini ve bundan geri dönüşün olmayacağını açıklayan bir belge olma özelliği ve demokrasiye geçişte ortaya çıkan sorunları ortaya koyma gibi bir özelliği de vardır. 12 Temmuz beyannamesi, çok partili demokratik düzenin tesisi için gerekli olan bir önlem olarak Türk siyasal hayatındaki yerini almıştır.

\section{Kaynakça}

Ahmad, F. (1992). Demokrasi Sürecinde Türkiye 1945-1980. İstanbul: Hil yayınlar1.

Ahmad, F. (2007). Demokrasi Sürecinde Türkiye 1945-1980. İstanbul: Hil yayınlar1.

Akın, F. (2005). 12 Temmuz Beyannamesi’nin Türk Siyasi Tarihindeki Yeri ve Önemi. Sosyal Bilimler Dergisi, 7(2), 92-109.

Akın, R. (2009). Gazi'den Günümüze Cumhurbaşkanlığı 1923-2007. İstanbul: Türkiye İş Bankası Kültür Yayınları.

Albayrak, M. (2004). Türk Siyasi Tarihinde Demokrat Parti 1946-1960. Ankara: Phoenix Yayınevi.

Altınkaş, E. (2012). Cumhuriyetin İlk Yıllarında İki Demokrasi Deneyimi: TPCF ve SCF. Akademik Bakış, 29, 1-16.

Arcayürek, C. (1983). Demokrasinin Illk Ylllarl 1947-1951. Ankara: Bilgi yayınevi.

Ateş, A. E. ve Gökçeler, O. (2019). 12 Temmuz Beyannamesinin Gölgesinde Cumhurbaşkanı İsmet İnönü’nün Yurt Gezileri. İnsan\&İnsan, 6 (21), 477-492.

Avcıŏglu, H. (1959). “Çok Partili Hayatın Ondördüncü Yılında İnönü ile Mülakat”. Akis, XVI, 269.

Çelebi, O. (2017). Taşradan Demokrasiye Açılan Kapı: İsmet İnönü’nün 14-26 Eylül 1947 Tarihli Yurtiçi Gezisi. Uluslar Arası Sosyal Araştırmalar Dergisi, 10(54), 279-295.

Çiçek, A.C. (2018). Türkiye'de Çok Partili Siyasal Hayatın 'Garanti Belgesi': 12 Temmuz Beyannamesi’nin Söylem Analizi. Curr Res Soc Sci, 4(2), 83-96.

Dereli, U. (1996). Recep Peker'in Başbakanlık Durumu. Marmara Üniversitesi SBE, (Yayımlanmamış Yüksek Lisans Tezi), İstanbul. 
Eroğul, C. (1998). Demokrat Parti Tarihi Ve İdeolojisi. Ankara: İmge Kitabevi.

Gökçeler, O. (2018). 1946-1950 Yılları Arasında İsmet Inönü’nün Cumhurbaşkanlı̆̆

Ve Yönetim Anlayışı, İstanbul Üniversitesi SBE, (Yayımlanmamış Yüksek Lisans Tezi), İstanbul.

Kara, N. (1984). Türkiye'de Çok Partili Sisteme Geçiş Kararının Nedenleri. Yapıt, 8, 64- 75.

Karasar, N. (1991). Bilimsel Araştırma Yönetim. Ankara: Sanem.

Karpat, H. K. (1996). Türk Demokrasi Tarihi. İstanbul: Alfa Yayıncılık.

Karpat, K. H. (2008). Türk Demokrasi Tarihi Sosyal, Ekonomik, Kültürel Temeller. Ankara: İmge Kitabevi.

Nalbant, Ş. G. (2014). Türkiye'de Merkez Sağın Kuruluşu: Demokrat Parti'nin Gözünden Cumhuriyet Halk Partisi. Adnan Menderes Üniversitesi SBE, (Yayımlanmamış Yüksek Lisans Tezi), Aydın.

Öztürkci, A. (2019). Türk Siyasal Tarihinde Demokrat Parti Birinci Büyük Kongresi. Cedrus VII, 723-740.

Sat1, S. (2019). Asım Us’un Milletvekilliği Döneminde Yakın Tarihimizin Önemli Olaylarına Bakışı (1927-1950). Karamanoğlu Mehmet Bey Üniversitesi SBE, (Yayımlanmamış Yüksek Lisans Tezi), Karaman.

Tuna, S. (2006). Siyasi Açıdan I. Ve II. Hasan Saka Hükümetleri (1947-1949). Gazi Üniversitesi SBE, (Yayımlanmamış Yüksek Lisans Tezi), Ankara.

Tunaya, T. Z. (1952). Türkiye'de Siyasi Partiler 1859-1952. İstanbul: Arba yayınları.

T.B.M.M. Tutanak Dergisi, (1946-1947). Dönem 8, C.İ-VI.

Uçan, M. (2014). İsmet İnönü’nün Siyasi Hayatı 1922-1960. Gazi Üniversitesi SBE, (Yayımlanmamış Yüksek Lisans Tezi), Ankara.

Ugan, A. A. (2014). Ísmet İnönü Dönemi Türkiye’sinin İç Ve Dış Politikasına Genel Bir Bakış (1938- 1950). Muğla Sıtkı Koçman Üniversitesi SBE, (Yayımlanmamış Yüksek Lisans Tezi), Muğla.

Yücel, S. (2001). Demokrat Parti. İstanbul: Ülke Kitapları.

Zürcher, E. J. (2006). Modernleşen Türkiye’nin Tarihi. Çev., Yasemin Saner Gönen, İstanbul: İletişim Yayınları. 


\section{EK-1 12 TEMMUZ BEYANNAMESI}

Hükümet Reisi ile ve Muhalefet Lideri ile son günlerde memleketin iç durumu üzerindeki konuşmalarımı ve bu hususta kanaatlerimi ve fikirlerimi söylemek zamanı gelmiştir. 7 Haziran tarihinde görüşmek üzere çağırdığım Bay Celal Bayar bana Demokrat Partinin, idare mekanizmasının baskısı altında bulunduğunu beyan ve şikayet etti. Haberdar ettiğim Başbakan, aynı mevzuları daha evvel aralarında görüştüklerini hikaye ederek, böyle bir baskının olmadığını, idare mekanizmasının memleketin huzurunu bozacak mahiyetteki tahriklere karşı çok güç durumda kaldığını beyan eyledi. Bundan sonra, iki tarafi bir arada dinlemek için, 14 Haziran tarihli buluşmayı tanzim ettim. Başbakan ve Yardımcısı Devlet Bakanı ile Demokrat Parti Genel Başkanı hazır bulundular. İki taraf arasında karşılıklı tartışma içinde iki buçuk saat devam eden bu konuşma, başladığı noktada bitti. Demokrat Parti Başkanı, partisinin baskı altında bulunduğu noktasında 1srar ve partisinin kanun dışı maksatlar ve ihtilal usulleri takip ettiğine dair ithamları reddetti. Hükümet Reisi, idare mekanizmasının baskı yaptığı iddiasını kabul edemeyeceğini ve şikayet vesikalarını tetkik ve takibe hazır olduğunu tekrar söyledi ve Muhalif Partinin çalışma usullerini düzeltmesi lazım olduğu iddiasında kaldi.

17 Haziran tarihinde Bay Bayar'1 tekrar kabul ettim. Bana, vaziyeti arkadaşlarıyla görüştüğünü, benim durumuma karşı teşekkürle mütehassıs olduklarını söyledikten sonra, baskı vardır kanaatinde olduklarını ifade eyledi. Bunun üzerine; iki defa görüştüğüm Başbakan, iktidar partisiyle muhalefet partisinin Büyük Meclisteki münasebetleri ve karşılıklı çalışmaları yolunda hayırlı terakkiler olduğunu takdirle söyledikten sonra, biz de kendimize düşen vazifeleri sadakatle ifa edeceğiz, size söz veriyorum dedi ve iki ay sonra Büyük Meclis toplanıncaya kadar partilerin münasebetlerinde itimadı artıran terakkiler olacağına ümidinin kuvvetli olduğunu ilave eyledi.

Bu beyanatı Bay Bayar'a 21 Haziran tarihinde naklettim. Bay Bayar, bu konuda fiili neticeye intizar edilmesi lazım geleceğini bildirdi. Bundan sonraki tartışmalar Muhalefet Liderinin Sivas nutkunda ve Hükümet Reisinin 2 Temmuz tarihli beyanatında ve ondan sonraki karşılıklı cevaplarda görülmüştür. Vaziyet hulasa olunursa, iki taraf şikayetlerinde ve savunmalarında ısrar etmiş ve şiddetli tartışmalar esnasında karşıllıklı iyi niyetlerin ifadesi olan bazı tatmin edici parçalar hatırlarda kalmıştır. Siyasi havayı yumuşatan bir iyilik olmak üzere, dertleri bilenlerin, kendiliklerinden, karşı tarafı teskin edici tedbirler alacakları ümidi uyanmış̧ır. Bunun dışında olarak, durum, Muhalefet Partisi Liderinin "fiili bir netice beklemek" şeklinde ifade ettiği hükümde görülür. Yani, bir başka türlü söylenirse, vaziyet karşılıklı iddialar bakımından düğüm halini muhafaza etmiştir. Şimdi ben, bu düğümü çözmeğe çalışacağım. İki tarafın şikayet ve müdafaalarının delillerini tafsil etmekte fayda görmüyorum. Zaten bunlar umumi efkarca da kafi derecede bilinmektedir. Gördüm ki, taraflardan hangisinin haksız, yahut hangisinin daha evvel karşısını kırmağa başlamış olduğunu aramakta da fayda yoktur. Ben, idare mekanizmasının baskı yaptığını Hükümet Başkanının kabul etmemesini, öyle bir hareketi tasvip etmeyeceğini katiyetle 
beyan eylemesini, bir teminat ifadesi olarak aldım ve bunu Bay Bayar'a söyledim. Ben, Muhalefet Liderinin kanundışı maksatlar ve metotlar isnadını reddetmesini, muhalif parti çalışması için şart olan kanun içinde kalmak esasının göz önünde tutulduğuna ve tutulacağına dair tatmin edici bir teminat olarak kabul ettim ve Başbakana bunu söyledim. Her iki tarafla uzun konuşmalardan çıkardığım bu neticelere inanmak istiyorum ve inanıyorum. Bizi bu inanışa getiren bu durumu, memlekette siyasi partilerin çalışıp gelişebileceğine kati ümit veren en mühim merhale sayıyorum. Şimdiye kadar, memlekette geçen iktidar ve muhalefet tecrübesinin muvaffak olmamasını, bir seneden beri geçirdiğimiz tecrübelere, onların dayanamamış ve bu günkü siyasi durumu elde edememiş olmalarında görüyorum. Benim kanaatimce, bir buçuk seneden beri geçirdiğimiz tecrübeler ağır ve bazen ümit kırıcı olmuştur; amma, gelecek için her türlü ümitleri haklı çıkaracak bir muvaffakiyet temin edilmiştir. $\mathrm{Bu}$ durumu muhafaza etmek onun gelişmesini sağlamak, iktidar ve muhalefet partilerinin vazifeleri olmak lazımdır. Gelecek için tedbirler, benim kabul ettiğim gibi, şu noktadan hareket etmekle bulunabilir. Benim, bu son dinlediğim karşılıklı şikayetler içinde mübalağa payı ne olursa olsun, hakikat payı da vardır. İhtilalci bir teşekkül değil, bir kanuni siyasi partinin metotları ile çalışan muhalif partinin, iktidar partisi şartları içinde çalışmasını temin etmek lazımdır. Bu zeminde ben, Devlet Reisi olarak, kendimi her iki partiye karşı müsavi derecede vazifeli görürüm. İdare mekanizması, yani Valilerimiz ve maiyetleri, bir seneden beri çok ağır bir tecrübe geçirmişlerdir. Öyle zamanlar oldu ki, memlekette hükümetin mevcut olup olmadığı bile şüphe götürür.idi.

Sorumlu Hükümetin huzur ve asayiş vazifesi münakaşa götürmez. Fakat, meşru ve kanuni siyasi partilere karşı tarafsız, eşit muamele mecburiyeti, siyasi hayat emniyetinin temel şartıdır. $\mathrm{Bu}$ arada, siyasi partilere mensup olan veya görünen hususi maksat sahiplerinin şirretliklerini pervasız olarak tesirsiz bırakmak hususunda partilerin dikkat göstermeleri icap eder. Siyasi partilerin hangisi işbaşına gelirse gelsin, onları, idare mekanizmasında çalışanların, haklarına ve itibarlarına karşı adaletli bir zihniyette olacaklarına inandıracaklardır. Zannediyorum ki, Hükümet Reisi ile Muhalefet Lideri arasındaki son tartışmada, iki tarafi sebat ettikleri noktadan ayırmak gayretine düşmeksizin, her iki tarafın bekledikleri şeyleri söylemiş ve temin etmiş oluyorum.

Vatandaşlarıma, Hükümetle ve iktidar partisi ile muhalefet partisi arasında görüşme ve araya girme safhalarını olduğu gibi anlatmış olduğumu ümit ederim. Varmak istediğim netice, başlıca iki parti arasında temel şartın, yani emniyetin yerleşmesidir. Bu emniyet, bir bakımdan memleketin emniyeti manasını taşıdığı için, benim gözümde çok ehemmiyetlidir. Muhalefet, teminat içinde yaşayacak ve iktidarın kendisini ezmek niyetinde olmadığından müsterih olacaktır. Büyük vatandaş kütlesi ise, iktidarın bu partinin veya öteki partinin elinde bulunması ihtimalini vicdan rahatlığı ile düşünebilecektir. $\mathrm{Bu}$ neticeye varmak için karşılaştı̆̆ım güçlükler, çok zaman, yalnız ruhi mahiyette olan amillerdir. Bu güçlükleri yenmek için, siyasi hayatımızı idare eden, iktidarda veya muhalefetteki liderlerin samimi yardımlarını isterim. Bu beyanatımı, neşrinden önce, Başbakanla Muhalefet Lideri görmüşlerdir. 

and its Effect on Turkish Political Life

12 Temmuz 1947

T.C. Cumhurbaşkanı

İSMET İNÖNÜ

\section{EK-2 BAŞBAKAN RECEP PEKER'İN İSTIFA MEKTUBU}

Cumhurbaşkanlığı Yüksek Katına,

Son dönemde sağl1k durumumun büsbütün bozulması türlü sebeplerle ağırlaşan vazife yükünü taşımama imkan bırakmadığından istifamın kabul buyrulmasını istirham ederim.

Yakında hükümetten ayrılan ve hükümete girmiş bulunanlarda dahil olmak üzere bütün mesuliyet arkadaşlarımın vazifelerini başarma hususundaki değerli vasıflarını taktirle kaydederek, haklarında yüksek teveccühlerini dilerim.

İş ve diş bütün devlet işlerinde güçlükleri yenmek için çabalarken bizlerden esirgemediğiniz tesirli yardımlarınızdan dolayı minnettarlık duygularımı arz ederim.

Tazimlerimle Başbakan Recep Peker

\section{EK-3 İSMET İNÖNÜ'NÜN RECEP PEKER'E CEVABI}

Çekilme mecburiyetinizde olduğunuzu bildiren yazınızı teessürle okudum. Sizin ve değerli arkadaşlarınızın bir seneyi geçen bir zamandan beri ağır devlet vazifelerinde gösterdiğiniz gayret ve fedakârlığı takdirle yad ederek teşekkürlerimi takdim ederim....

Çekilmeniz kabul edilmiştir. Yeni hükümet kuruluncaya kadar vekil olarak vazife arkadaşlarınızla beraber devam etmenizi rica ederim.

Cumhurbaşkanı 